\title{
Risk assessment of possible impacts of climate change and irrigation on wheat yield and quality
}

Jianchao Liu ${ }^{\mathrm{a}, \mathrm{b}}$, Wenbing Yao ${ }^{\mathrm{a}}$, Zhanglin Peng ${ }^{\mathrm{a}}$, Yuhang Fu ${ }^{\mathrm{a}}$, Xingduo Fan ${ }^{\mathrm{a}}$, Hangjun Wang ${ }^{\mathrm{a}}$

a Jiyang College of Zhejiang A\&F University, Zhuji 311800, Zhejiang, China

${ }^{\mathrm{b}}$ Institute of Water Saving Agriculture in Arid Areas of China, Northwest A\&F University, Yangling 712100, Shaanxi, China

\begin{abstract}
The effects of climate change on yield and quality for different climate regions had high uncertainty. Risk assessment is an effective measure to assess the seriousness of the projected impacts for decision-makers. The modified quality model was used to simulate integrated impacts of climate change, environment and management on wheat yield and quality. Then, the Canadian Earth System Model (CanESM2) was used to forecast the daily meteorological data, and Statistical Down Scaling Model was used for downscaling. CERESWheat was combined with the forecasted meteorological data to simulate the future wheat yield and grain protein concentration (GPC). The risk of wheat yield and quality in three climatic regions of Shaanxi combined with two climate change scenarios of CanESM2 were assessed. Temperature increased $0.22-3.34{ }^{\circ} \mathrm{C}$ and precipitation increased 10-60 mm for RCP4.5 and RCP8.5. Elevated temperature and precipitation had positive effects on yield in all regions. The yield risk of most regions with climate change decreased 3.8\%-25.1\%. The GPC risk of all regions with climate change decreased 7.3\%-27.2\%. Irrigation decreased yield risk greatly in all regions, while had totally different effects for the three climatic regions. Yield risk with irrigation decreased $37.7 \%-52.1 \%$ in different climate. In contrast to previous studies, GPC risk with irrigation increased greatly $25.8 \%-28.9 \%$ in humid region, $3.9 \%-8.8 \%$ in sub-humid region, and decreased $37.7 \%-52.1 \%$ in semi-arid region. Climate change decreased yield risk and GPC risk together. While irrigation decreased yield risk greatly in all regions, had totally different effects for the three climatic regions.
\end{abstract}

Key words: climate change; wheat quality; risk assessment; irrigation; CERES-Wheat; yield

\section{Introduction}

Under monsoon climates in which the annual precipitation fluctuates greatly, the quality and yield of grain are seasonally variable because rainfall is unreliable and there is a significant risk of heat waves during the grain-filling phase[1]. It is anticipated that under climate change, the growing-season rainfall in many arable cropping regions will change, and there will be a greater incidence of extreme climatic events[2]. The change in precipitation in different climatic regions will not be the same, but more extreme precipitation events will 
likely occur[3]. At the same time, climate change can result in entirely different effects on the grain protein concentration (GPC). GPC is a function of genes, environment, and management. GPC has important effects on nutritional, flour yield, and processing quality[4]. A GPC of approximately $8 \%$ is suitable for pastry and cookies, and a GPC of $13-14 \%$ is suitable for leavened bread and pasta. Steamed bread and white salted noodles (Chinese style noodles) should have a medium protein content (approximately 10\%)[5]. When the environment or management are less than optimal for wheat, the resulting GPC may not match the intended end use of the wheat[6].

The artificial climate chamber, open top chamber, and free-air carbon dioxide enrichment methods are the most widely used methods to study the effect of climate change on crop growth. However, these are different from the natural environment or are very expensive. The combination of general circulation models (GCMs) and crop models assesses the effects of climate change on cropping systems and is more comprehensive and convenient, but it depends on the progress of theory. Crop model has often been used to evaluate the effect of climate change on yield[7], but its effect on quality has been scarcely reported[8]. CERES-Wheat can interpret and simulate nitrogen movement and transfer in the soil-plant-atmosphere-continuum (SPAC), but it cannot output parameters related to quality such as GPC. Much crop models just simulated GPC by harvest index or constant nitrogen-to-protein conversion factor $(\mathrm{Fp}), 5.70$. It is very necessary to add quality module for crop model so as to simulate grain quality with different stresses.

GCMs are used for climate prediction[9] but cannot be directly used for climatic studies because of their coarse spatial resolution[10]. The Canadian Earth System Model (CanESM2), based on the Coupled Model Intercomparison Project Phase 5 (CMIP5), and reanalysis from the National Center for Environmental Prediction (NCEP) have been verified in China[11]. The simulation of precipitation and temperature had better results[12]. Downscaling is necessary to extract location-scale information from the climatic data downloaded from GCMs[13]. Statistical downscaling methodologies and dynamical downscaling approaches are common downscaling methods[14]. Statistical downscaling methodologies have several advantages, such as low cost, easy operation, and rapid calculation[15]. The Statistical Down Scaling Model (SDSM V5.2) is a statistical downscaling methodology that has been widely used in China[16].

Risk is a combination of two factors: the probability that an adverse event will occur and the consequences of the adverse event. Risk assessment encompasses an analysis phase and an implementation phase: risk treatment[17]. By comparing the outputs of a multi-simulation with a critical threshold, it is possible to evaluate the risk related to future climate conditions. Climate change has important effects on grain quality, but adaptation 
to climate change has long been neglected in terms of quality. The most commonly used methods to alleviate the impact of climate change are changing the sowing date, newly cultivated varieties, and reasonable irrigation[18]. Irrigation is the most common and simple management approach. Irrigation can improve the nitrogen use efficiency of crops, but it has an adverse effect on winter wheat protein accumulation[19].

The wheat quality response to climate change can also vary depending on the location and climate change scenario. Simulation modeling provides an opportunity to understand the broad-scale feedback between climate change and agro-production systems at a regional level. Based on modified CERES-Wheat model could better response GPC to stresses, and the modified CERES-Wheat was able to simulated GPC with abiotic stress from climate change more precisely. Twelve locations representative of a humid region, sub-humid region, and semiarid region were selected. These locations also represent major portions of the Shaanxi winter wheat ecosystem. This study focuses on the assessment of the risk of durum wheat yield and GPC under climate change as well as the risk treatment-irrigation.

\section{Materials and Methods}

\subsection{Experimental Location and Treatments}

The field experiment, conducted from Oct. 2014 to Jun. 2017, was located at Guanzhong-irrigation area, where the average annual precipitation is $580 \mathrm{~mm}$, the average precipitation in wheat growing season, the average annual temperature and the annual sunshine duration were $203 \mathrm{~mm}, 13{ }^{\circ} \mathrm{C}$, and $2196 \mathrm{~h}$, respectively. The wheat variety "Xiaoyan 22" (Triticum aestivum L.) was widely grown in northwest and north China. The 4 irrigation treatments (I0, rain fed; I1, $60 \mathrm{~mm}$; I2, $120 \mathrm{~mm} ; \mathrm{I} 3,180 \mathrm{~mm}$ ) involved the whole plots. The 4 fertilizations (N0, $0 \mathrm{~kg} \mathrm{~N} \mathrm{hm}^{-2} ; \mathrm{N} 1,105 \mathrm{~kg} \mathrm{~N} \mathrm{hm}^{-2} ; \mathrm{N} 2,210 \mathrm{~kg} \mathrm{~N} \mathrm{hm}^{-2} ; \mathrm{N} 3,315 \mathrm{~kg} \mathrm{~N} \mathrm{hm}^{-2}$ ) were the split plot treatments. Wheat grain samples were weighed from 0.1000 to $0.20000 \mathrm{~g}$ and determined the grain nitrogen content by Kjeldahl apparatus (JELTEC 2300, Sweden FOSS). The soil samples were collected and dried in an oven to measure soil water content.

\subsection{Simulation of GPC based on modified CERES-Wheat model}

CERES-Wheat model was widely used crop models to simulate wheat development, growth and yield (Fig. 1) ${ }^{[32-34]}$. The CERES-Wheat could output the yield, grain nitrogen yield at maturity (GNAM), Water stress ( $\left.\mathrm{S}_{\mathrm{W}}\right)$, and nitrogen stress $\left(S_{N}\right)$. The calculation of Fp (Eq. 1) is determined by $S_{W}$ and $S_{N}$ [20]. GPC (Eq. 2) was simulated by the GNAM, yield, and Fp, as follows[21]: 


$$
\begin{gathered}
F p=-5.46 \times \operatorname{MIN}\left(S_{W}, S_{N}\right)+5.72 \\
G P C=\frac{\operatorname{GNAM}}{Y I E L D} \times F p \times 100
\end{gathered}
$$

Where Fp is nitrogen-to-protein conversion factor, dimensionless; $\mathrm{S}_{\mathrm{W}}$ is the water stress factor, dimensionless; $\mathrm{S}_{\mathrm{N}}$ is the nitrogen stress factor, dimensionless.

\subsection{Weather data}

Daily maximum and minimum temperature $\left({ }^{\circ} \mathrm{C}\right)$, precipitation $(\mathrm{mm})$, and solar radiation $\left(\mathrm{MJ} \mathrm{m}^{-2} \mathrm{~d}^{-1}\right)$ are the essential weather data for CERES-Wheat[22]. The weather data included historical weather data and climate scenario data.

\subsubsection{Historical weather data}

Historical weather data were obtained from the China Meteorological Data Network (http://data.cma.cn/site/index.html), including daily maximum and minimum temperature, precipitation, and sunshine hours. The daily solar radiation data required by the crop model were calculated at the site level using the Ångström-Prescott equation[23].

\subsubsection{Climate scenario data.}

For scenarios of future climate change, the IPCC AR5 uses representative concentration pathways (RCPs)[24]. RCPs describe four pathways by different modeling groups: a stringent mitigation scenario (RCP2.6, warming less than $2{ }^{\circ} \mathrm{C}$ ), two intermediate scenarios (RCP4.5, radiative forcing $4.5 \mathrm{Watts}^{-2}$; and RCP 6.0, radiative forcing 6.0 Watts $\mathrm{m}^{-2}$ ), and one scenario with very high greenhouse gas emissions (RCP8.5,

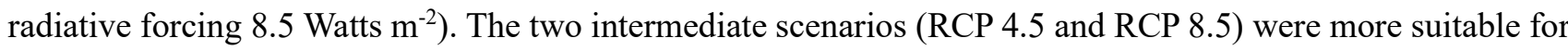
China because of its economic development, greenhouse gas emissions, and land use[25].

The climate change scenario was obtained using CanESM2 at a grid size of $2.8125^{\circ}$. The reanalysis weather data of the climatic scenario were downloaded from the NCEP (http://climate-scenarios.canada.ca/?page=predcanesm2). These data included 26 atmospheric predictors variables (e.g., mean sea level pressure, $850 \mathrm{hPa}$ zonal velocity, total precipitation, mean temperature at $2 \mathrm{~m}$ ) for the period 1961-2005 and GCM projections for RCPs (RCP4.5 and RCP8.5) for the period 2006-2100[26].

\subsection{Calibration and validation}

Calibration was completed running GLUE[27]. Related data were from a treatment of sufficient irrigation and sufficient fertilization (I3N3) from 2014-2015. 
Model validation was completed by comparing measured and simulated soil water content, yield, and GPC from 2015-2017. Three evaluation indicators were used to test the accuracy. The percent deviation (d) (Eq. 3) is percentage of deviation. The smaller the relative root mean square error (RRMSE) (Eq. 4) is, the smaller the difference in the measured and simulated values (0-0.1, excellent; 0.1-0.2, good; 0.2-0.3, fair and $>0.3$, poor). And $\mathrm{r}^{2}$ (Eq. 5) was used to assess the downscaled climatic projection, and the best indexes were 1.

$$
\begin{gathered}
d=\frac{s_{i}-o_{i}}{o_{i}} \times 100 \% \\
R R M S E=\frac{\sqrt{\sum_{i=1}^{n} \frac{\left(s_{i}-o_{i}\right)^{2}}{n}}}{\sum_{i=1}^{n} \frac{o_{i}}{n}} \times 100 \% \\
r^{2}=\frac{\left(\sum_{i=1}^{n}\left(s_{i}-\sum_{i=1}^{n} \frac{s_{i}}{n}\right) \cdot\left(o_{i}-\sum_{i=1}^{n} \frac{o_{i}}{n}\right)\right)^{2}}{\sum_{i=1}^{n}\left(s_{i}-\sum_{i=1}^{n} \frac{s_{i}}{n}\right)^{2} \cdot \sum_{i=1}^{n}\left(o_{i}-\sum_{i=1}^{n} \frac{o_{i}}{n}\right)^{2}}
\end{gathered}
$$

where $s_{i}$, is the simulated value, $o_{i}$ is the observed value, and $n$ is the sample size.

\subsection{Scenarios}

Due to the long and narrow topography in Shaanxi province, different cropping systems are used in different regions. To make the results more explanatory and uniform, the management parameters were set as follows: fertilization was $210 \mathrm{~kg} \mathrm{~N} \mathrm{hm}^{-2}$ before sowing; the sowing dates were October 1-15, when the daily average temperature was above $20^{\circ} \mathrm{C}$ and precipitation was less than $2 \mathrm{~mm}$; the cultivation method was rotary tillage; the plant population density was 240 seeds $\mathrm{m}^{-2}$; and the harvesting time occurred when winter wheat had matured. The scenarios included irrigation $(60 \mathrm{~mm}$ during wheat wintering, and $60 \mathrm{~mm}$ during the elongation stage) and rainfed (no irrigation). Soil data from 12 locations were used for CERES-Wheat and collected from the China Soil Database (http://vdb3.soil.csdb.cn/) (Table 1). The change in $\mathrm{CO}_{2}$ concentration was not considered. A greater uncertainty in simulating wheat yields under climate change was due to response mechanism of rising $\mathrm{CO}_{2}$ concentration than to variations among downscaled general circulation models. (Uncertainty in simulating wheat yields under climate change).

\subsection{Risk assessment}

To estimate risk of wheat yield and quality, the yield and GPC were compared with a critical threshold, 
calculated as the 60-year mean yield and GPC for the historical period (1957-2017). The risk of wheat yield and GPC shortfall was then defined as the relative frequency of yield and GPC below the threshold, representing the likelihood of future yield and GPC being lower than the historical mean yield and GPC. The risk of yield (Eq. 8) and GPC (Eq. 9) are estimated as:

$$
\begin{gathered}
M_{\mathrm{i}}=\left\{\begin{array}{l}
1, Y_{\mathrm{i}} \leq \bar{Y} \\
0, Y_{\mathrm{i}}>\bar{Y}
\end{array} \text { and } R=\frac{\sum_{i=1}^{n} M_{i}}{n} \times 100 \%\right. \\
M_{\mathrm{i}}^{\prime}=\left\{\begin{array}{l}
1, G P C_{\mathrm{i}} \leq \overline{G P C} \\
0, G P C_{\mathrm{i}}>\overline{G P C}
\end{array} \text { and } R^{\prime}=\frac{\sum_{i=1}^{n} M_{i}^{\prime}}{n} \times 100 \%\right.
\end{gathered}
$$

where R and R' are the risk of yield and GPC, respectively, \%; M and M' are the determination factors of yield and GPC, respectively; Y is yield, $\mathrm{kg} \mathrm{hm}^{-2} ; \bar{Y}$ is the 60-year mean yield for the historical period (1957-2017), $\mathrm{kg} \mathrm{hm}^{-2}$; GPC is the grain protein content, \%; $\overline{G P C}$ is the 60 -year mean GPC for the historical period (19572017), \%.

\section{Results}

\subsection{Calibration and validation}

\subsubsection{CERES-Wheat}

The percent deviation values between simulated and observed phonological period, yield, grain nitrogen concentration $\left(\mathrm{G}_{\mathrm{N}}\right)$, and evapotranspiration $(\mathrm{ET})$ were all less than 0.1 , implying that the model simulated the phenology, wheat growth, nitrogen transformation, and water transformation well (Table 2). The genetic coefficients were Relative stable and could be used in same or similar 12 sites.

Comparing the simulated values to the observed values of yield (Fig. 2a) and GPC (Fig. 2b) under the 16 treatments from 2015-2017, the data were distributed near the 1:1 line. The RRMSE was 0.035 and 0.07, respectively. The values were all less than 0.1 , so CERES-Wheat could simulate water and nitrogen stress against winter wheat yield and GPC well. However, CERES-Wheat underestimated the effects of severe nitrogen stress (N0), as the observed values were greater than the simulated values. GPC was overestimated with slight nitrogen stress (N1).

\subsubsection{SDSM}

The daily maximum temperature, daily minimum temperature, monthly total precipitation and monthly 
total radiation downscaling were selected as the predictor variables. SDSM was calibrated for the period of 1961 to 1990 using these predictors. For validating the reliability of the calibrated SDSM, the simulated result from 1991-2005 was compared to the observed data from 1996 to 2005. The coefficient of determination $\left(\mathrm{r}^{2}\right)$ for these linear relationships varied from 0.64 to 0.93 (Table 3). A very significant power correlation between the predictand and predictor variables $(\mathrm{p}<0.001$ level) was evident.

\subsection{Analysis of historical and future climate}

The terrain of Shannxi is long and narrow, and the extent of latitude is very large. The annual average temperature is $2.8-11.6{ }^{\circ} \mathrm{C}$ during the wheat growing season. The temperature to the south is higher and gradually decreases from south to north (Fig. 3a). The sub-humid and semi-arid regions warmed faster and increased by $0.92{ }^{\circ} \mathrm{C}$ in RCP 4.5. Tongchuan in the sub-humid region increased by $1.01{ }^{\circ} \mathrm{C}$. The smallest increase for a location was Fengxiang in the sub-humid region, which increased by $0.22{ }^{\circ} \mathrm{C}$. The speed of increase was consistent throughout Shaanxi in RCP8.5. The temperature increased by $0.85-0.98{ }^{\circ} \mathrm{C}$ compared to RCP 4.5. The temperatures of Yanan, Wuqi, Tongchuan in sub-humid region increased the most rapidly, by 1.80, 2.05, and $3.34{ }^{\circ} \mathrm{C}$, respectively. The situations in the humid and semi-arid regions were the same, as the average temperature increased $1.70^{\circ} \mathrm{C}$.

The precipitation during the growth period gradually decreased from south to north. The available precipitation in the semi-arid region during growth period was scarcer (Fig. 3b). Precipitation in the all regions increased with RCP4.5. However, for some locations such as Wuqi, precipitation decreased very little. The precipitation situation was similar with RCP8.5. The average precipitation during the growth period increased by approximately $13 \%$ compared to historical precipitation.

\subsection{Phenology}

The flowering stage and mature stage with RCP4.5 and RCP8.5 were brought forward (Fig. 4a, b). The performances of the three climatic regions were similar. The grain filling duration of humid region was almost constant with climate change (Fig. 4c). But the grain filling duration of sub-humid and semi-arid regions with RCP4.5 and RCP4.5 was brought forward.

\subsection{Winter wheat yield and risk}

Winter wheat yield with latitude increasingly showed a tendency of increasing first and then decreasing. The average historical yield at the 12 locations ranged from 3849 to $9434 \mathrm{~kg} \mathrm{hm}^{-2}$ and had extreme variation 
under rainfed conditions. The maximum yield was $9434 \mathrm{~kg} \mathrm{hm}^{-2}$ and $9025 \mathrm{~kg} \mathrm{hm}^{-2}$ in Fuping and Shangluo in the humid region, respectively. The minimum yield was $3849 \mathrm{~kg} \mathrm{hm}^{-2}$ in Wuqi in the semi-arid region (Fig. 5).

The average yield in the humid region decreased by $0.2-14.1 \%$ with RCP 4.5 . The western area of the humid region significantly declined more than did the eastern area. The southern part of the sub-humid region also decreased by $0.4-1.0 \%$, but the northern yield increased by $16.1-52.7 \%$. The yield in the semi-arid region increased slightly, by $7.5-10.3 \%$. The average yield with RCP8.5 in the humid region and the southern subhumid region increased slightly, but both yields were lower than the historical; that of the northern sub-humid region and the semi-arid region increased significantly.

Irrigation significantly changed the impact of climate change on yield. However, with the coupling effects of irrigation and climate change, the yield of the humid region decreased with increasing radiative forcing, but the yield of the semi-arid region increased. The yield of the sub-humid region remained approximately the same.

The yield risk of humid region increased 3.8\% with RCP4.5(Fig. 6a). While the yield risk of sub-humid region and semi-arid region with RCP4.5 decreased $12.8 \%$ and 5.9\%, respectively. The yield risk of humid region, sub-humid region and semi-arid region decreased with RCP8.5 12.8\%, 15.7\% and 25.1\%, respectively. Yield risk with irrigation decreased 52.1\% with historical climate, 50.5\% with RCP4.5 and 37.7\% RCP8.5, respectively (Fig. 6b).

\subsection{Grain protein content and risk}

The historical GPC from south to north decreased first, and then increased (Fig. 7a). That of the humid and semi-arid regions increased to $11.69 \%$ and $11.88 \%$ for RCP4.5, respectively. However, the sub-humid region decreased to $10.94 \%$ (Fig. 7b). With the continuously increasing radiative forcing, the GPC of the humid and semi-arid regions unexpectedly decreased to $11.49 \%$ and $11.27 \%$ for RCP8.5, respectively (Fig. 7c). The subhumid region increased to $10.97 \%$.

Irrigation had a negative effect on GPC in the humid and sub-humid regions and a positive effect on GPC in the semi-arid region (Fig. 8). The GPC of the humid and sub-humid regions decreased $1.11 \%$ and $0.81 \%$, respectively. However, the GPC of the semi-arid region increased $0.77 \%$ (Fig. 8a). The historical GPCs of Fuping, Shangluo, and Xi' an in central Shaanxi were the lowest.

With the coupling effect of irrigation and climate change, the GPC of the three regions had a different response. The average historical GPC of the semi-arid region was $11.76 \%$. However, the average historical GPC of the humid and sub-humid regions was only $10.09 \%$ and $10.45 \%$, respectively. The GPC of the humid and 
sub-humid regions was only slightly different. However, the GPC of the humid region increased $10.09 \%-10.60 \%$ with the increase in radiative forcing, whereas the GPC of the sub-humid region decreased from $10.45 \%$ to $10.22 \%$. The GPC of the semi-arid region was much greater than that of the humid and sub-humid regions. First, it increased from $11.76 \%$ to $12.41 \%$, and it then decreased to $11.77 \%$.

The GPC risk of humid region, sub-humid region and semi-arid region decreased with RCP4.5 14.8\%, 9.9\% and $23.8 \%$, respectively. (Fig. 9a). The GPC risk of humid region, sub-humid region and semi-arid region decreased with RCP8.5 27.2\%, 21.6\% and 7.3\%, respectively. GPC risk of humid region with irrigation increased greatly $26.0 \%$ with historical climate, $28.9 \%$ with RCP4.5 and 25.8\% RCP8.5, respectively (Fig. 9b). GPC risk of sub-humid with irrigation only increased 3.9\% with historical climate, 5.9\% with RCP4.5 and 8.8\% RCP8.5, respectively. While GPC risk of semi-arid region with irrigation decreased $24.25 \%$ with historical climate, $20.1 \%$ with RCP4.5 and 9.9\% RCP8.5, respectively.

\section{Discussion}

The future wheat yield and quality in China will face a challenge caused by climate change. A decline in GPC across fields from 1988-2012 was attributed to climate change[28]. Rising temperatures which shortened the growing period was the main impact on wheat yields[29]. While Asseng et al[30] reported that GPC and yield all increased with the new warmer climates.

In this study, we first used CERES-Wheat to simulate GPC using the nitrogen-to-protein conversion factor. Then, CanESM2 was selected to simulate daily meteorological data and SDSM was used to downscale. CERESWheat was combined with the simulated meteorological data to simulate the future wheat yield and quality in Shaanxi. The temperature and precipitation increased under RCP4.5 and RCP8.5. It is generally acknowledged that a temperature increase is beneficial to GPC, whereas increases in precipitation and irrigation are beneficial to yield, but harmful to GPC[31]. How yield and GPC change still needs further study. An irrigation scenario was also used as part of a strategy for responding to climate change. In the CERES-Wheat or other crop models, there was correlation between photosynthetic intensity and $\mathrm{CO}_{2}$. So, the yield was too much and GPC was too few, they differed from the actual situation. The mechanism of crop growth responding to increase in $\mathrm{CO}_{2}$ was uncertain. Thus, increasing $\mathrm{CO}_{2}$ was not considered this factor in this study which may make the results uncertain.

4.1 Evaluation of the simulation of GPC and yield 
An accurate simulation of phenology ensured wheat filling duration, which was the foundation of the accumulation of protein and dry matter, and the simulated yield was underestimated without nitrogen fertilization (N0). Yao et al[32] revealed that CERES-Wheat undervalued the capacity to resist stress.

The simulation of GPC was very good with severe water and nitrogen stress because GPC is the ratio of grain yield to grain nitrogen yield. The accumulation of nitrogen and dry matter during the grain-filling stage was more affected by temperature than it was by water and nitrogen stress[33]. However, the simulated results of GPC with slight nitrogen stress (N1) were overestimated. Asseng et al[34] found that the accumulation rate of nitrogen was overestimated when the average temperature was less than $10^{\circ} \mathrm{C}$.

\subsection{Effects of climate change and irrigation on yield and risk}

Precipitation and temperature increased with climate change, but the yield of different climatic regions responded differently to climate change. Water supply had an extremely significant positive correlation with yield for all of the climatic regions. Water supply will play a dominant role in determining future winter wheat yield[35]. The rising temperature could cause an increase in ET, and if the increase in precipitation is insufficient, the drought stress will be stronger[36].

The humid region had richer water and heat resources. Temperature and water were not the most important limiting factors for this region. The temperature and precipitation increased, but the yield only slightly decreased or increased. The reason may be that the yield in the humid region was at a higher level and had largely reached the potential yield, and the excess precipitation decreased radiation. The study of Wang[37] showed similar results: reference crop evapotranspiration and crop water requirements significantly decreased under climate change. Irrigation was still good for yield but only played a limited role.

Temperature in the sub-humid region increased and precipitation decreased for RCP4.5, while the winter wheat yield increased. Zhang and Yan[38] recognized that although precipitation decreased, the appropriate increase in temperature promoted growth of winter wheat. Radiation and temperature had the highest suitability in the sub-humid region, and they increased under climate change[39]. Decreasing precipitation becomes the main limiting factor in wheat yield, and water cannot match the increasing temperature. Much radiation is wasted. Thus, the increasing yield is mostly because of irrigation.

The main limiting factors on yield in the semi-arid region were low temperature and a shortage of water. Climate and cultivation conditions were not conducive to the growth of winter wheat. Climate change could compensate for these inadequacies. Winter wheat was suitable for high altitude and high latitude areas under 
the effects of climate change[40]. The influence of irrigation was greater. The effects of climate change increased the yield only slightly, but irrigation exponentially increased the yield. Water was still the greatest limiting factor on yield.

The decreasing of precipitation in humid regions was the main reason that the yield risk increased. While the increasing temperature and precipitation remain the yield stable, and the decreased yield risk of the other regions. Furthermore, the changes in the frequency of extreme climatic events also increased yield risk[41]. Water was still the main limitation factors affecting yield risk[42], and irrigation was best agricultural measures in adapting crop growth to climate change in all regions.

\subsection{Effects of climate change and irrigation on GPC}

Temperature and precipitation increase with increasing latitude, but GPC decreased first and then increased. High temperatures can affect the formation of carbohydrates and proteins influencing both GPC and yield. The optimum temperature for grain dry matter accumulation is $20.7 \pm 1.4{ }^{\circ} \mathrm{C}$ during the grain-filling period[43], and the optimum temperature for grain nitrogen accumulation is $35^{\circ} \mathrm{C}[22]$. At temperature $>30^{\circ} \mathrm{C}$, the rate of starch accumulation decreases, resulting in a higher GPC[44]. The humid region was more suitable for the accumulation of protein, and the sub-humid region was more suitable for the accumulation of dry matter. The semi-arid region had temperature and precipitation that were lower than optimal, and elevated temperature and precipitation were beneficial to the accumulation of protein and dry matter in this region.

GPC of the humid and semi-arid regions increased slightly under RCP4.5 and RCP8.5, but the reasons for the increase were not the same. The higher temperature of the humid region accelerates the rate of nitrogen accumulation in the grain and shortens the period of starch accumulation[45]. However, in the semi-arid region, lower temperature and less precipitation limit the accumulation of nitrogen and dry matter. Climate change eased the cold stress and drought stress and promoted both yield and GPC[46,47]. In the sub-humid region, GPC decreased for RCP4.5 and RCP8.5. The increasing yield in the sub-humid region was the greatest because of the suitable climate for RCP4.5 and RCP8.5. The GPC was diluted by the excess dry matter in the grain[18].

Irrigation would further promote yield, and GPC would continuously decrease. The GPC of the sub-humid region decreased slightly with climate change, and the GPC of the humid and sub-humid region declined markedly with irrigation. And so, its commercial and economic aspects were poor. Thus, it was recommended reduce the amount of irrigation in the humid and sub-humid region. Adequate water could mitigate the effects of heat stress. Irrigation improved the rate of nitrogen uptake, but the GPC decreases with the increasing 
yield[48]. The accumulation of protein is independent of grain dry matter accumulation, but a higher amount of dry matter dilutes GPC[49]. GPC has a negative correlation with yield in the humid and sub-humid regions, making it complicated to develop an effective management strategy to maximize profit. Irrigation was not suitable in the humid region. The contribution of irrigation to yield was limited, but GPC decreased in the humid region. Irrigation was the primary reason for $\mathrm{NO}_{3}-\mathrm{N}$ leaching[50], and it had a dilution effect on GPC[51].

Irrigation in the semi-arid region promoted yield and GPC. Xu and Yu recognized that severe water stress decreased the photosynthetic rate and nitrogen concentration and that irrigation plays an important role in the improvement of grain quality and yield in a semi-arid region[52].

The GPC risk of all the regions decreased with climate change. The cumulation of grain protein and starch during grain-filling period was two independent processes[53]. Starch accumulating rate would decrease when temperature was above $30^{\circ} \mathrm{C}$, while the grain protein accumulating rate was largely unaffected[54,55]. The grain protein accumulation was determined by temperature[22], so the GPC risk with RCP8.5 was less than that with RCP4.5. Irrigation increased grain starch and increasing temperature increased grain protein. The comprehensive effects of irrigation and increasing temperature caused the different results in the three climatic regions. Irrigation had the greater effect on yield for humid region, and the irrigation and increasing temperature had the same effect for semi-humid region. While low temperature was the main limiting factor for semi-arid region.

\section{Conclusions}

This study simulated and evaluated the risk of climate change and irrigation on yield and quality using a crop model and representative concentration pathways. The GPC and yield risks had different responses to climate change and irrigation, and irrigation should be discreetly applied for different climatic regions to combat climate change. The methodology has allowed us to assess the risk of crop yield and quality shortfall related to climate change and irrigation by assigning probability estimates instead of providing only uncertainty ranges.

(1) Temperature and precipitation increased. Elevated temperature and precipitation had positive effects on yield in all regions. The yield risk of most regions with climate change decreased 3.8\%-25.1\%.

(2) GPC in the humid and semi-arid regions increased for RCP4.5 and RCP8.5, but it decreased in the subhumid region. The GPC risk of all regions with climate change decreased 7.3\%-27.2\%.

(3) Irrigation decreased yield risk greatly in all regions, while had totally different effects for the three climatic regions. Yield risk with irrigation decreased 37.7\%-52.1\% in different climate. While GPC risk with 
irrigation increased greatly $25.8 \%-28.9 \%$ in humid region, $3.9 \%-8.8 \%$ in sub-humid region, and decreased $37.7 \%-52.1 \%$ in semi-arid region.

\section{Acknowledgements}

We are grateful for the financial support provide by the start-up funds of Jiyang College of Zhejiang A \& F University (RQ1905A01); the students' science and technology innovation project of Jiyang College (JYKC1910); the National High Technology Research and Development Program of China (2013AA102904), the National Natural Science Foundation of China (41371234), and the 111 Project of the Ministry of Education and the State Administration of Foreign Experts Affairs (B12007).

\section{References}

1. Ruml M, Vuković A, Vujadinović M, Djurdjević V, Rankovićvasić Z, et al. (2012) On the use of regional climate models: Implications of climate change for viticulture in Serbia. Agricultural \& Forest Meteorology s 158 - 159: 53-62.

2. IPCC (2013) Climate Change 2013: The Physical Science Basis. Contribution of Working 43: 866-871.

3. Xu Z, Liu Z (2014) Climate Change Scenarios and the Impact on Runoff. New York: Springer Netherlands. 311-357 p.

4. Meng ZJ, Duan AW, Dassanayake KB, Chen DL, Gao Y, et al. (2016) Effects of regulated deficit irrigation on grain yield and quality traits in winter wheat. Transactions of the ASABE 59: 897-907.

5. Addo K, Pomeranz Y, Huang ML, Rubenthaler GL, Jeffers HC (1991) Steamed bread. II. Role of protein content and strength. Cereal Chemistry 68: 39-42.

6. Albert W, Cynthia JH, Jaepil W (2003) Assessing Winter Wheat Responses to Climate Change Scenarios: A Simulation Study in the U.S. Great Plains. Climatic Change 58: 119-147.

7. Jabeen M, Gabriel HF, Ahmed M, Mahboob MA, Iqbal J (2017) Studying Impact of Climate Change on Wheat Yield by Using DSSAT and GIS: A Case Study of Pothwar Region. Quantification of Climate Variability, Adaptation: Springer. pp. 387-411.

8. Nuttall JG, O'Leary GJ, Panozzo JF, Walker CK, Barlow KM, et al. (2017) Models of grain quality in wheat - A review. Field Crops Research 202: 136-145.

9. Gaffin SR, Rosenzweig C, Xing X, Yetman G (2004) Downscaling and geo-spatial gridding of socio-economic projections from the IPCC Special Report on Emissions Scenarios (SRES). Global Environmental Change 14: 105-123. 10. Rajabi A, Shabanlou S (2015) The analysis of climate change uncertainty by means of SDSM model (case study: 
Kermanshah province, Iran). Agricultural Communications 3: 33-40.

11. Qing WU, Jiang X, Xie J (2017) Evaluation of Surface Air Temperature in Southwestern China Simulated by the CMIP5 Models. Plateau Meteorology 36: 358-370.

12. Song Y, Qiao F, Song Z, Jiang C (2013) Water Vapor Transport and Cross-Equatorial Flow over the Asian-Australia Monsoon Region Simulated by CMIP5 Climate Models. ADVANCES IN ATMOSPHERIC SCIENCES 30: $726-738$.

13. Meenu R, Rehana S, Mujumdar PP (2013) Assessment of hydrologic impacts of climate change in Tunga-Bhadra basin, India with HEC-HMS and SDSM. Hydrobiological Processes 27: 1572-1589.

14. Schmidli J, Frei C, Vidale PL (2006) Downscaling from GCM precipitation: a benchmark for dynamical and statistical downscaling methods. International Journal of Climatology 26: 679-689.

15. Timbal B, Dufour A, Mcavaney B (2003) An estimate of future climate change for western France using a statistical downscaling technique. Climate Dynamics 20: 807-823.

16. Zhai W, Pengjun LI, Lin K, Zhang F (2016) The Prediction of Climatic Change and Runoff Response in the Dongjiang Basin Based on SDSM-SWAT Model. Pearl River 37: 1-6.

17. Omenn G. Framework for Environmental Health Risk Management: Final Report; 1997.

18. Y L, P YY, Q Z, L WZ (2011) Changes of Glutenin subunits due to water-nitrogen interaction influence size and distribution of glutenin macropolymer particles and flour quality. Crop Science 51: 2809-2819.

19. Rodríguez-Félix F, Ramirez-Wong B, Torres-Chávez PI, Álvarez-Avilés A, SERGIO-MORENO-SALAZAR S (2014) Yellow berry, protein and agronomic characteristics in bread wheat under different conditions of nitrogen and irrigation in northwest mexico. Pakistan Journal of Botany 46: 221-226.

20. Liu J, Feng H, He J, Chen H, Ding D (2018) The effects of nitrogen and water stresses on the nitrogen-to-protein conversion factor of winter wheat. Agricultural water management 210: 217-223.

21. McKenzie RH, Bremer E, Grant CA, Johnston AM, DeMulder J, et al. (2006) In-crop application effect of nitrogen fertilizer on grain protein concentration of spring wheat in the Canadian Prairies. Canadian Journal of Soil Science 86: $565-572$.

22. Jones JW, Hoogenboom G, Porter CH, Boote KJ, Batchelor WD, et al. (2003) The DSSAT cropping system model. European Journal of Agronomy 18: 235-265.

23. Wong LT, Chow WK (2001) Solar radiation model. Applied Energy 69: 191-224.

24. Team CW, Pachauri RK, Meyer LA (2014) Climate Change 2014: Synthesis Report. Contribution of Working Groups I, II and III to the Fifth Assessment Report of the Intergovernmental Panel on Climate Change. Journal of Romance Studies 4: $85-88$. 
25. Xin CH (2017) effects of different mulching applications on greenhouse gas emissions and their responds on future climate change scenrios. YANGLING, SHANNXI: Northwest A\&F University. 54-56 p.

26. Khadka D, Pathak D (2016) Climate change projection for the marsyangdi river basin, Nepal using statistical downscaling of GCM and its implications in geodisasters. Geoenvironmental Disasters 3: 1-15.

27. J H, Dukes MD, Jones JW, Graham WD, Judge J (2009) Applying GLUE for estimating CERES-MAIZE genetic and soil parameters for sweet corn production. Transactions of the ASABE 52: 1907-1921.

28. Peltonen-Sainio P, Salo T, Jauhiainen L, Lehtonen H, Sieviläinen E (2015) Static yields and quality issues: Is the agrienvironment program the primary driver? Ambio 44: 544-556.

29. Asseng S, Ewert F, Martre P, Rötter RP, Lobell DB, et al. (2015) Rising temperatures reduce global wheat production. Nature climate change 5: 143.

30. Asseng S, Martre P, Maiorano A, Rötter RP, O Leary GJ, et al. (2019) Climate change impact and adaptation for wheat protein. Global change biology 25: 155-173.

31. Horstmann B (2008) Framing adaptation to climate change - a challenge for building institutions. Bonn: Deutsches Institut für Entwicklungspolitik gGmbH. 1-57 p.

32. Yao N, Zhou Y, Song L, Liu J, Li Y, et al. (2015) Parameter estimation and verification of DSSAT-CERES-Wheat model for simulation of growth and development of winter wheat under water stresses at different growth stages. Transactions of the Chinese Society of Agricultura 31: 138-150.

33. Ritchie JT, Otter S (1985) Description and performance of CERES-Wheat: A user-oriented wheat yield model. ARS wheat yield project: 159-175.

34. Asseng S, BarTal A, Bowden JW, BA, Van Herwaarden A, et al. (2002) Simulation of grain protein content with APSIM-Nwheat. European Journal of Agronomy 16: 25-42.

35. Wang J, Li WE, De Li Liu (2011) Modelling the impacts of climate change on wheat yield and field water balance over the Murray - Darling Basin in Australia. Theoretical and Applied Climatology 104: 285-300.

36. Panozzo J, Cassandra KW, Partington DL, Neumann NC, Tausz M, et al. (2014) Elevated carbon dioxide changes grain protein concentration andcomposition and compromises baking quality. A FACE study. Journal of Cereal Science: 461470.

37. Guang WW, Zhang PS, Zhao SF, Qiu XW, Feng LY, et al. (2012) Spatiotemporal variations of rice irrigation water requirements in the mid-lower reaches of Yangtze River under changing climate. Advances in Water Science 23: 656-664. 38. Xiang ZJ, Ping YJ (2003) Evaluation Model of Wheat Yield in Regional Response to Climate Change. Journal of Arid Land Resources and Environment 17: 85-90. 
39. Jing X, Fu-ning Z (2013) Impact of Demographic Transitionon Food Demand in China: 2010 - 2050. China Population, Resources and Environment 23: 117-121.

40. Zheng LF, Shang YF, Li XJ, Feng H, Wei YS (2017) Structural equation model for analyzing relationship between yield and agronomic traits in winter wheat..

41. Semenov S, Patwardhan A, Burton I, Oppenheimer M, Pittock AB, et al. Assessing key vulnerabilities and the risk from climate change; 2007. pp. 779-810.

42. Moriondo M, Giannakopoulos C, Bindi M (2011) Climate change impact assessment: the role of climate ex tremes in crop yield simulation. Climatic Change 104: 679-701.

43. Porter JR, Gawith M (1999) Temperatures and the growth and development of wheat: a review. European Journal of Agronomy 10: 23-36.

44. Jenner CF (1994) Starch Synthesis in the Kernel of Wheat Under High Temperature Conditions. Functional Plant Biology 21: 791-806.

45. Singh IR, Majumdar SP (2015) Effects of nutrients and compaction levels on amino acids and protein content in wheat (Triticum aestivum L.) grain. International Journal of Agricultural Sciences 11: 1-6.

46. Wesley AS, Lukow OM, Rih MK, Ames N, Brown D (2001) Effect of multiple substitutions of glutenin and gliadin proteins on flour quality of Canada Prairie Spring. Cereal Chemistry 78: 69-73.

47. Stone PJ, Nicolas ME (1996) Varietal Differences in Mature Protein Composition of Wheat Resulted From Different Rates of Polymer Accumulation During Grain Filling. Functional Plant Biology 23: 727-737.

48. Zhang YL (2008) Effects of irrigation amount on the nitrogen uptake, distribution, use, grain yield and quality in wheat. Acta Agronomica Sinica 34: 870-878.

49. Groos C, Robert N, Bervas E, Charmet G (2003) Genetic analysis of grain protein-content, grain yield and thousandkernel weight in bread wheat. Tag.theoretical \& Applied Genetics.theoretische Un 106: 1032-1040.

50. Min YX, An TY, Yun YX, Lin LX, Suo ZF (2000) Effect of irrigation and precipitation on soil nitrate nitrogen accumulation. JOURNAL OF SOIL WATER 14: 71-73.

51. Yan JD, Wen YZ, Zhu XZ (2011) Effects of irrigation amount and nitrogen fertilization rate on wheat yield and soil nitrate content. Chinese Journal of Applied Ecology 22: 364-368.

52. Xu ZZ, Yu ZW (2006) Nitrogen metabolism in flag leaf and grain of wheat in response to irrigation regimes. Journal of Plant Nutrition and Soil Science 169: 118-126.

53. Vos J (1981) Effects of temperature and nitrogen supply on post-floral growth of wheat; measurements and simulations. Landbouwhogeschool. 
54. Jenner CF (1994) Starch Synthesis in the Kernel of Wheat Under High Temperature Conditions. Functional Plant Biology 21: 791-806.

55. Altenbach SB, Dupont FM, Kothari KM, Chan R, Johnson EL, et al. (2003) Temperature, Water and Fertilizer Influence the Timing of Key Events During Grain Development in a US Spring Wheat. Journal of Cereal Science 37: 9-20. 


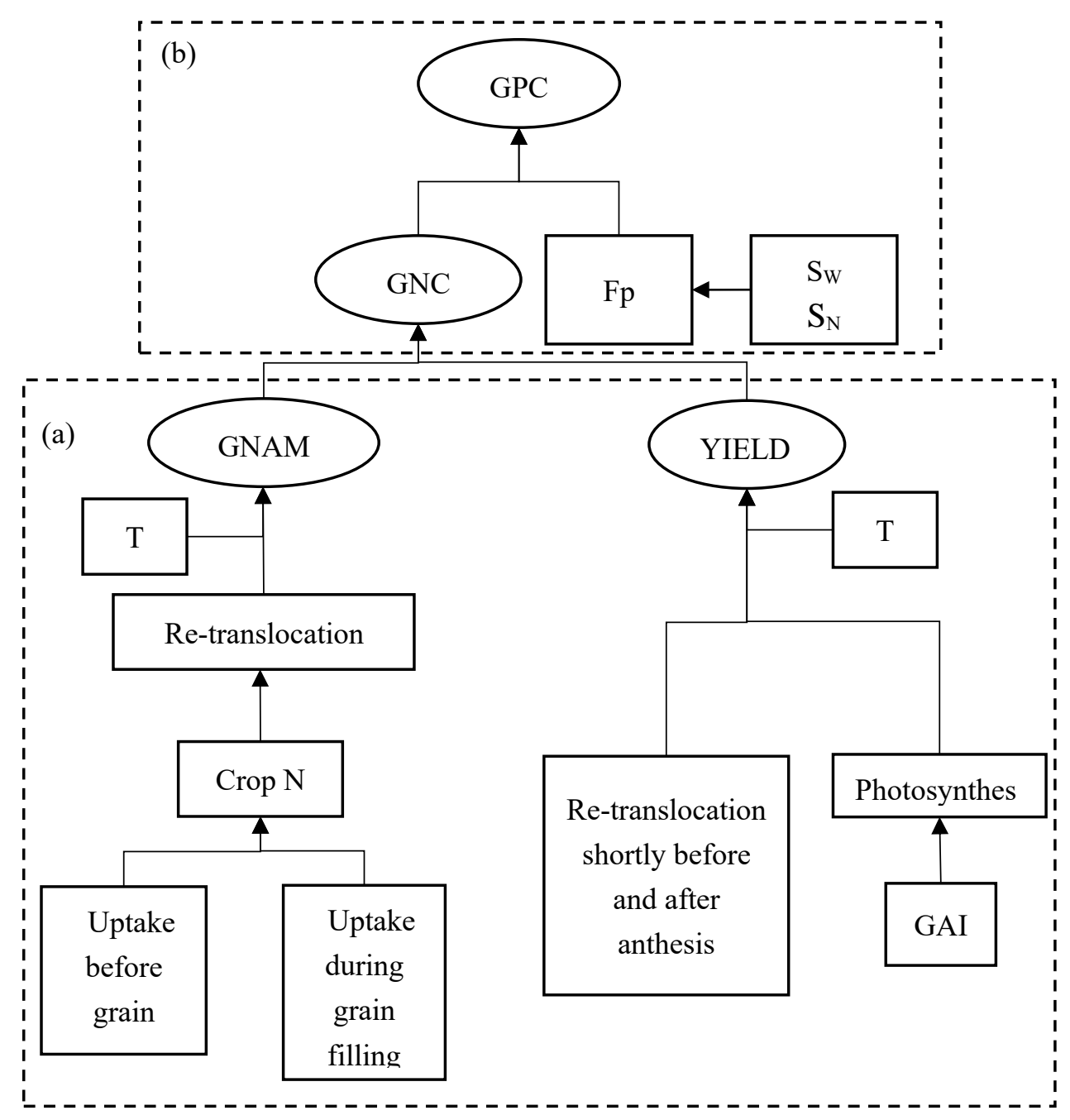

Fig. 1. CERES-Wheat structure (a) for grain nitrogen yield at maturity (NUCM) and grain yield at maturity (HWAM) simulation, and grain protein concentration (GPC) (b) for grain nitrogen concentration (GNC), and GPC. (Fp-nitrogen to protein conversion factor, T-temperature, GAI-green leaf area index, $\mathrm{S}_{\mathrm{W}}$ water stress, $\mathrm{S}_{\mathrm{N}}$-nitrogen stress, RLD-root length density distribution.) 

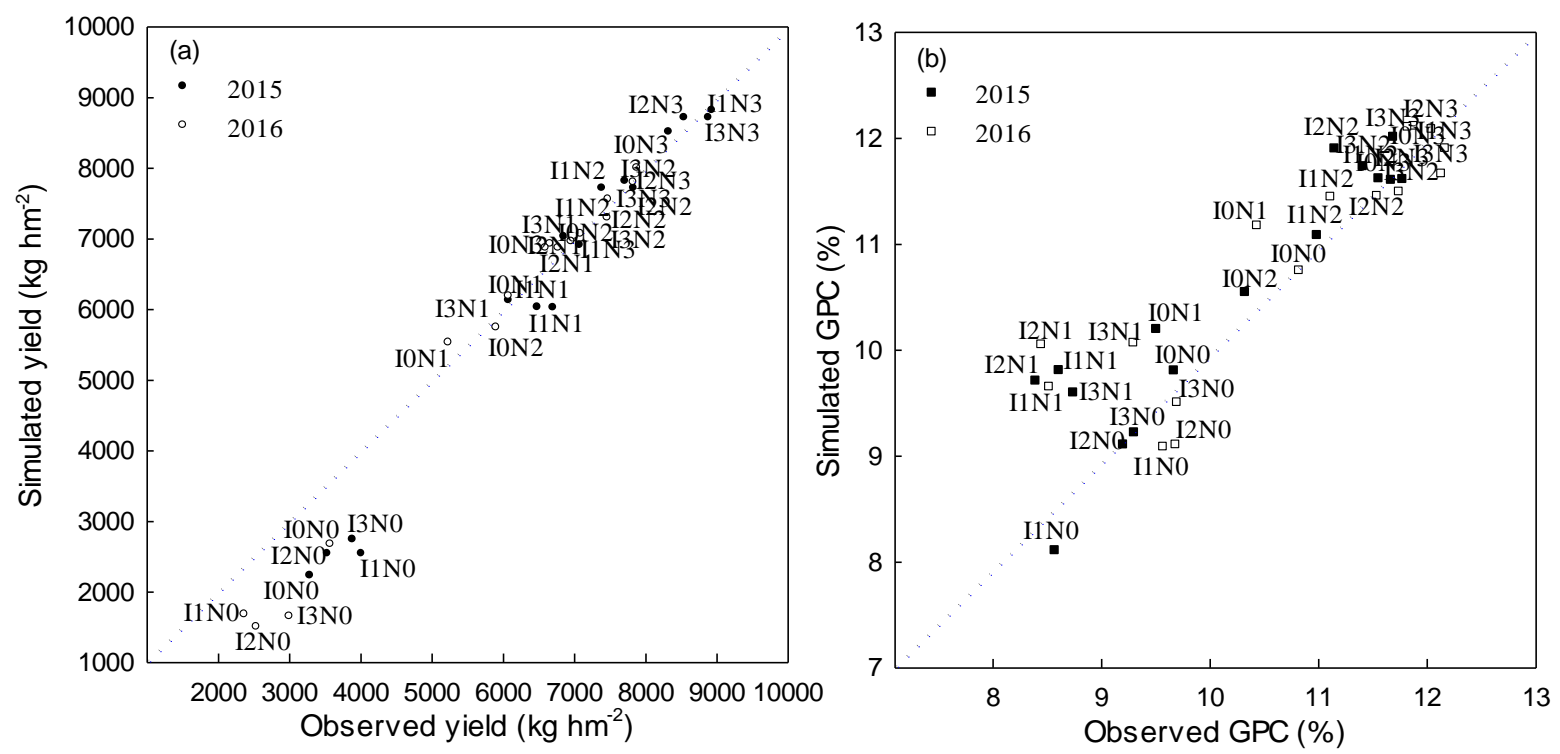

Fig. 2 Observed values $v$ s. simulated values of yield (a) from 2015 (•) to $2016(\circ)$, and grain protein concentration (GPC) (b) from 2015 (घ) to 2016 ( $\square$ ), for 16 different irrigation and fertilization fertilizer treatments during the two growing seasons of 2015-2017. The dotted line is the 1:1 line. 

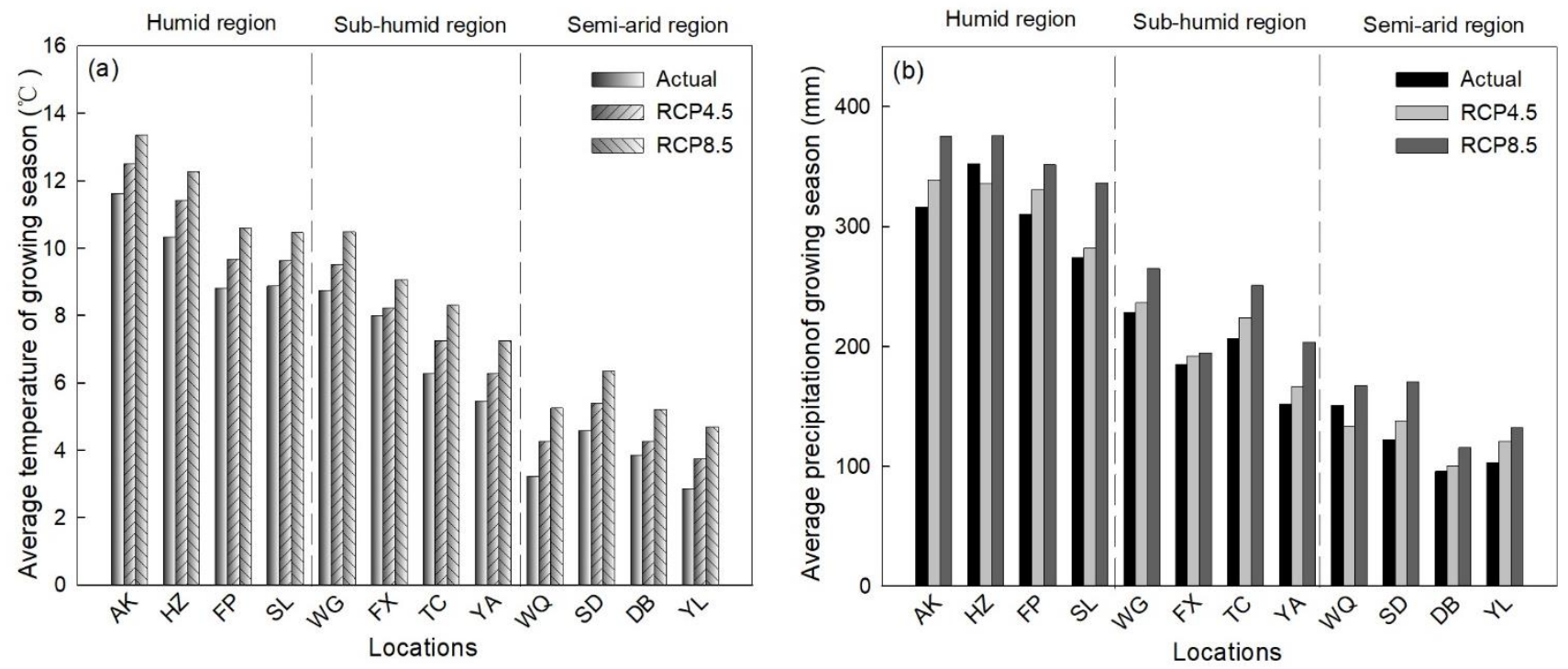

Fig. 3 Average temperature (a) and precipitation (b) of historical conditions and those projected by radiative forcing 4.5 Watts $\mathrm{m}^{-2}(\mathrm{RCP} 4.5)$ and radiative forcing $6.0 \mathrm{Watts}^{-2}(\mathrm{RCP} 8.5)(\mathrm{c})$ during the growing season of winter wheat. 

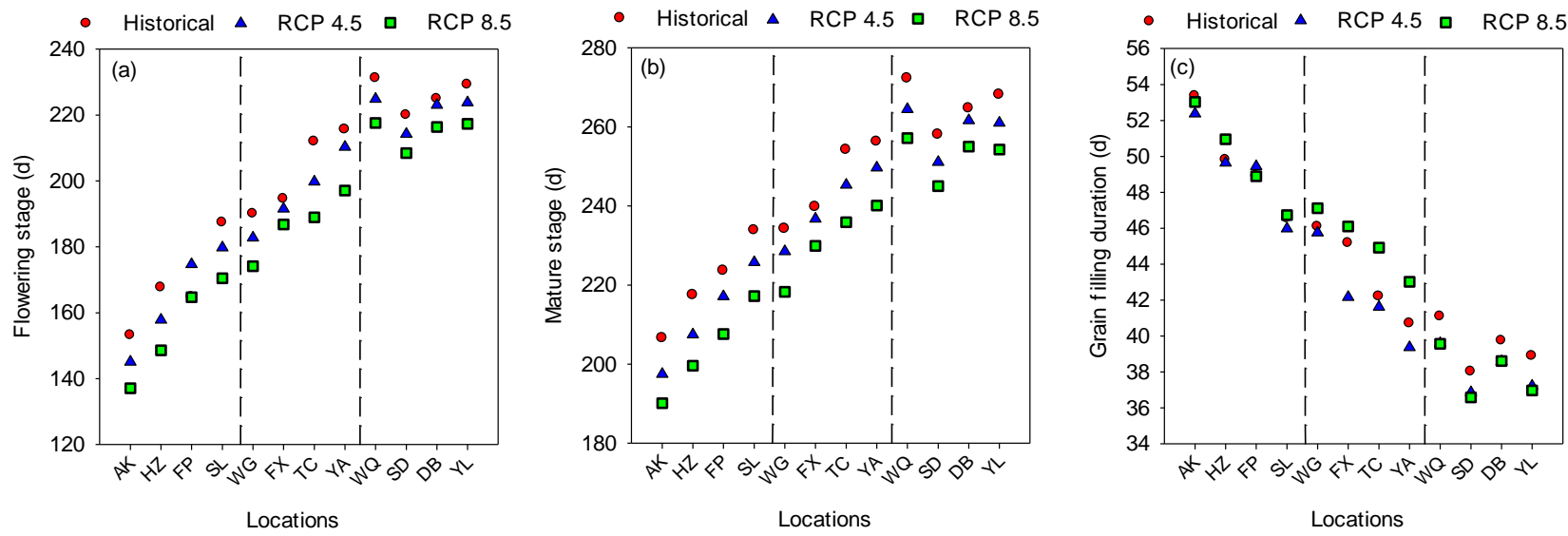

Fig. 4 Flowering stage (a), mature stage (b), and grain filling duration (c) with historical climate $(\bullet)$, radiative forcing 4.5 Watts $\mathrm{m}^{-2}(\mathrm{RCP} 4.5)(\mathbf{\Delta})$, and radiative forcing 6.0 Watts $\mathrm{m}^{-2}(\mathrm{RCP} 8.5)(\square)$. 


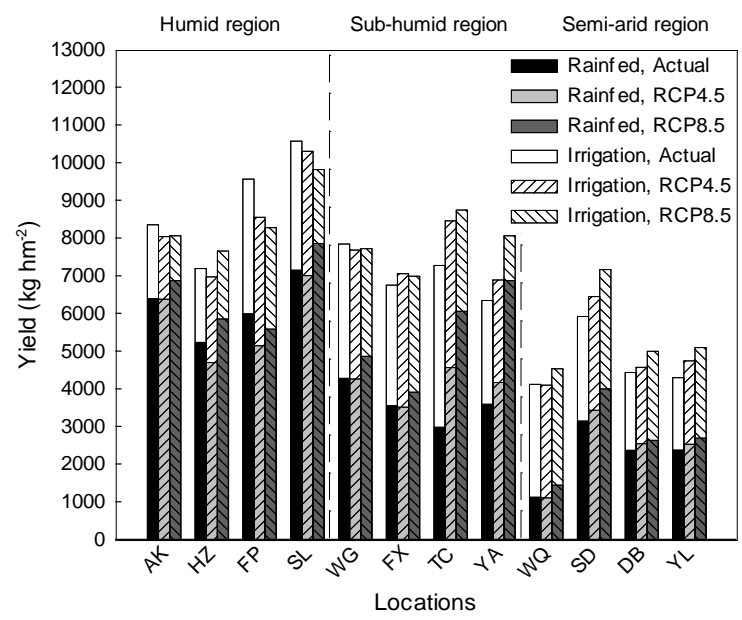

Fig. 5 Rain fed (different grey levels) and irrigated (different gradients) winter wheat yield with historical climate (first column), radiative forcing 4.5 Watts $\mathrm{m}^{-2}$ (RCP4.5) (second column), and radiative forcing 6.0 Watts $\mathrm{m}^{-2}$ (third column). 

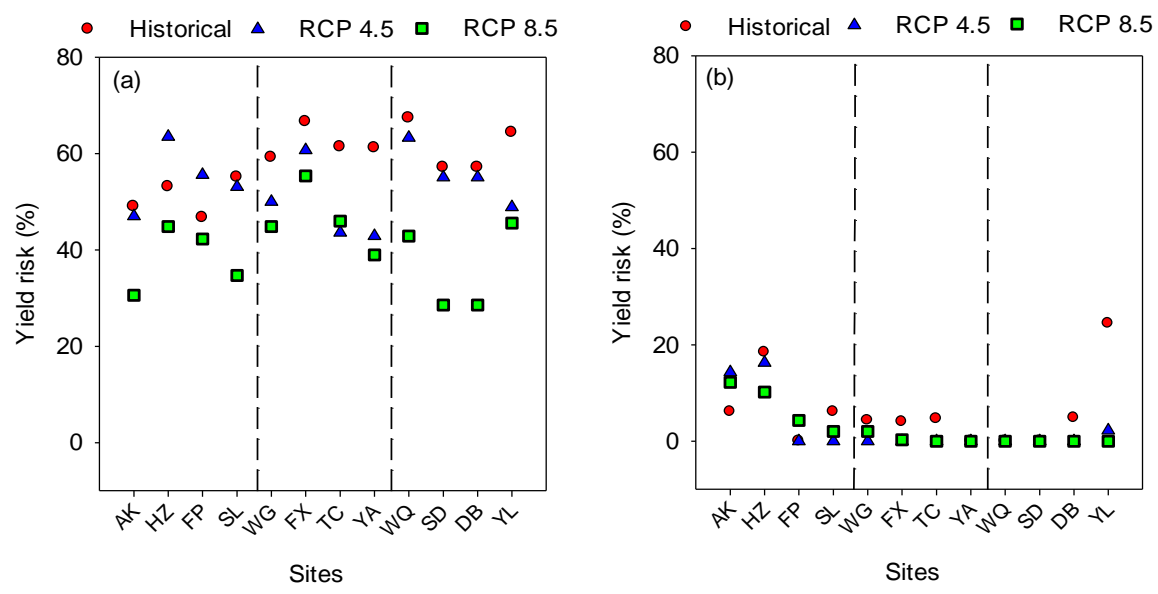

Fig. 6 Yield rick of rainfed (a) and irrigation (b) with historical climate (O), radiative forcing $4.5 \mathrm{Watts}^{-2}(\mathrm{RCP} 4.5)$ $(\boldsymbol{\Delta})$, and radiative forcing 6.0 Watts $\mathrm{m}^{-2}(\mathrm{RCP} 8.5)(\square)$. 

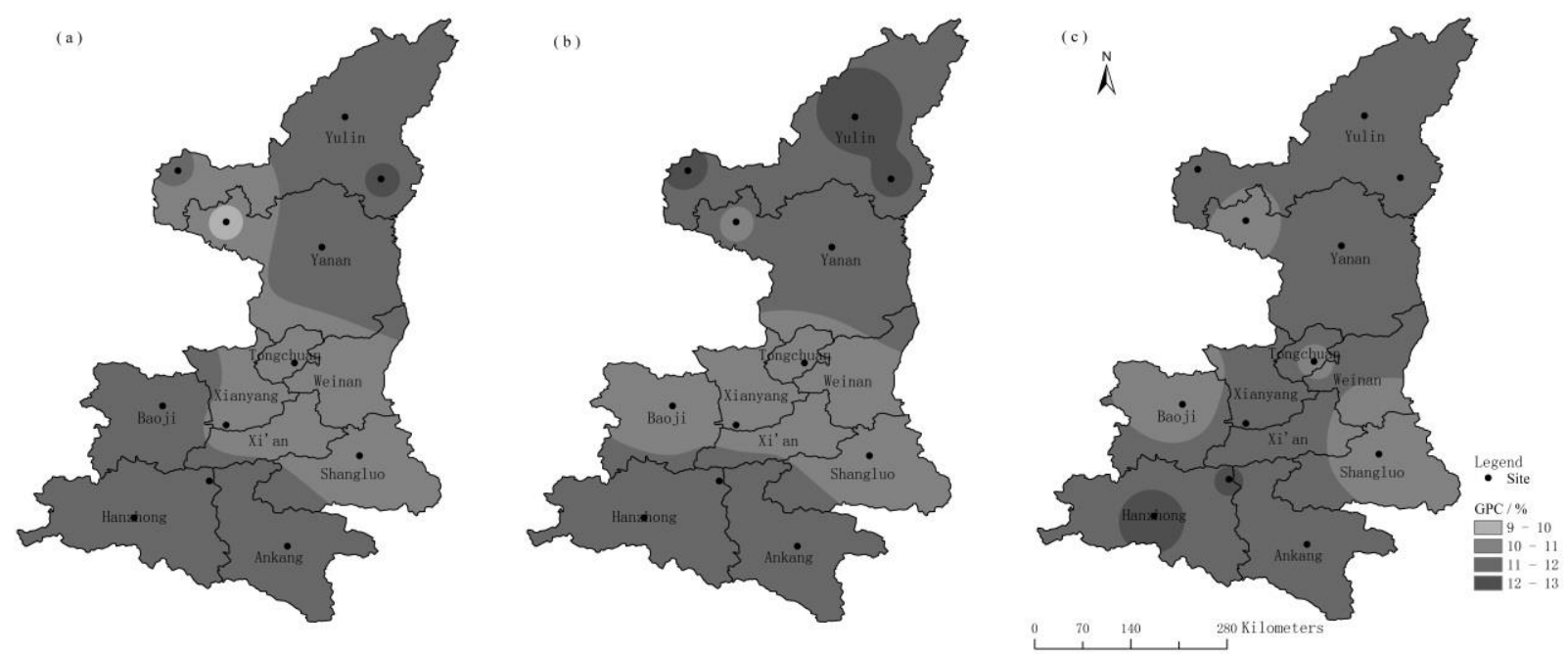

Fig. 7 Grain protein concentration (GPC) under rainfed conditions, and the data of historical climate (a), radiative forcing 4.5 Watts $\mathrm{m}^{-2}$ (RCP4.5) (b), and radiative forcing 6.0 Watts $\mathrm{m}^{-2}$ (RCP8.5) (b). 

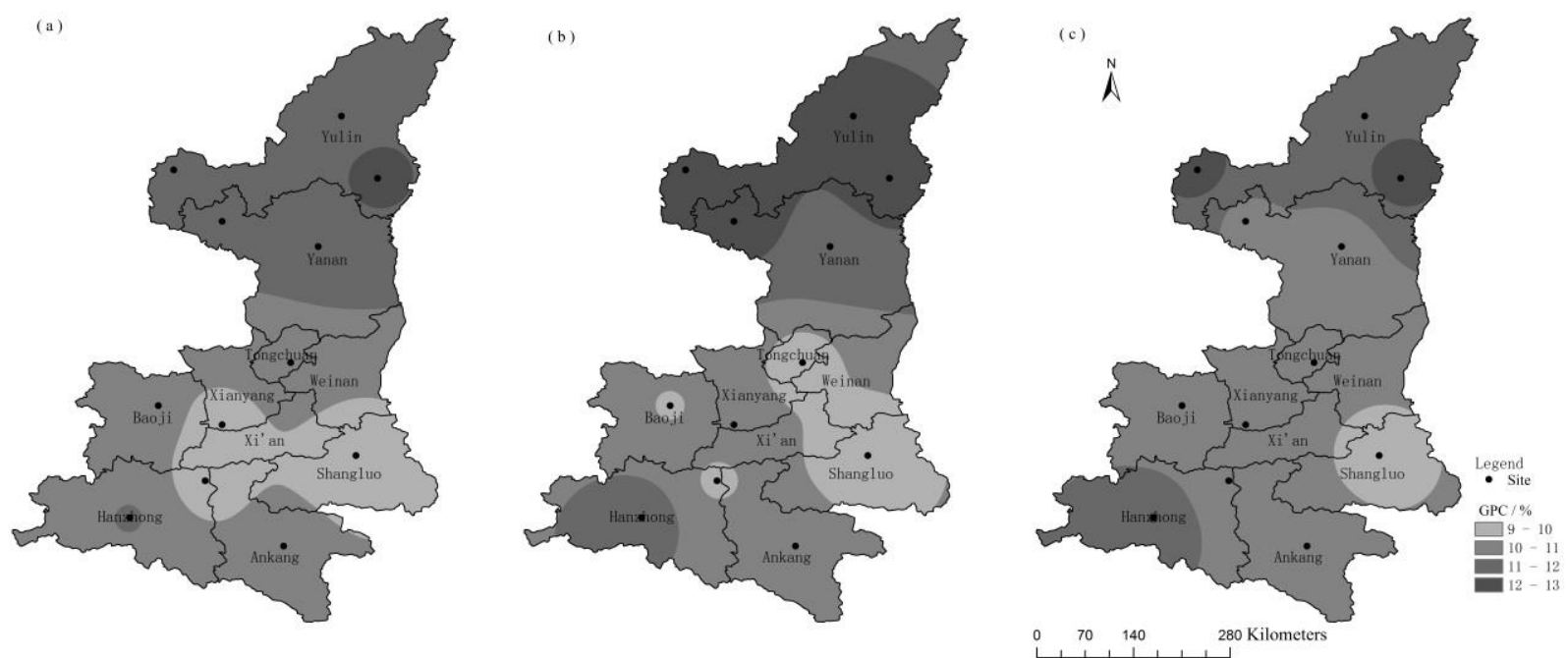

Fig. 8 Grain protein concentration (GPC) under irrigation conditions, and the data of historical climate (a), radiative forcing 4.5 Watts $\mathrm{m}^{-2}$ (RCP4.5) (b), and radiative forcing 6.0 Watts $\mathrm{m}^{-2}$ (RCP8.5) (b). 

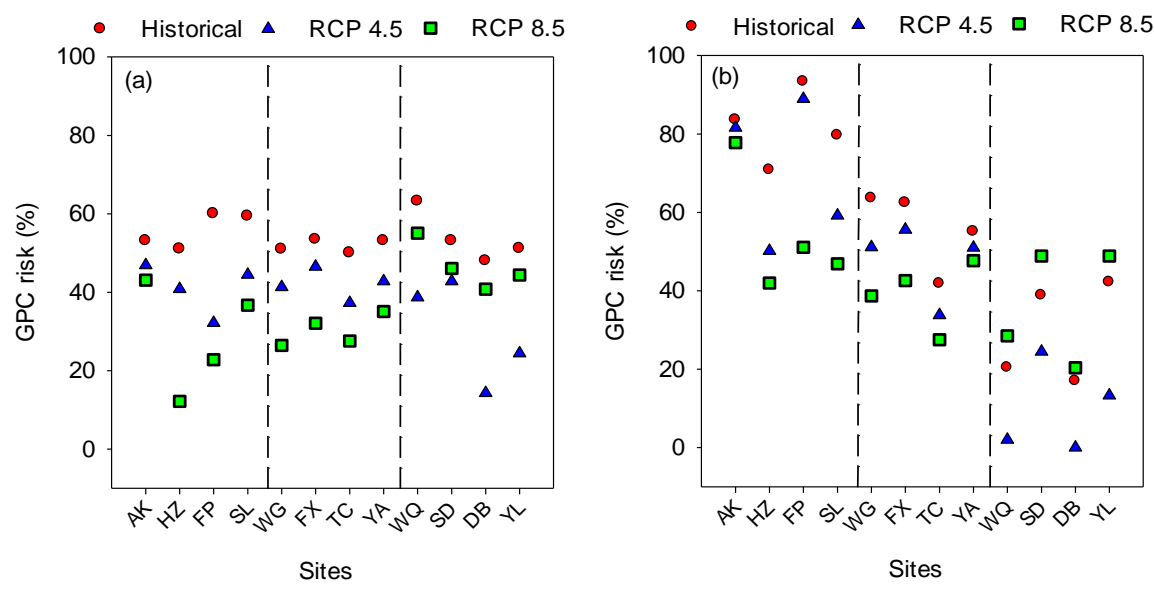

Fig. 9 Grain protein concentration (GPC) rick of rainfed (a) and irrigation (b) with historical climate (•), radiative forcing 4.5 Watts $\mathrm{m}^{-2}(\mathrm{RCP} 4.5)(\boldsymbol{\Delta})$, and radiative forcing 6.0 Watts $\mathrm{m}^{-2}(\mathrm{RCP} 8.5)(\square)$. 
Table 1 Twelve site locations in Shaanxi, China, and their climatic information

\begin{tabular}{|c|c|c|c|c|c|c|c|}
\hline Climate & Site & $\begin{array}{c}\text { Latitude } \\
\left(^{\circ}\right)\end{array}$ & $\begin{array}{c}\text { Longitude } \\
\left(^{\circ}\right)\end{array}$ & $\begin{array}{l}\text { Altitude } \\
\text { (m) }\end{array}$ & $\begin{array}{c}\text { Soil organic } \\
\text { matter } \\
(\%)\end{array}$ & $\begin{array}{c}\text { Mean temperature } \\
\text { during growing } \\
\text { period }\left({ }^{\circ} \mathrm{C}\right)\end{array}$ & $\begin{array}{c}\text { Precipitation during } \\
\text { growing period } \\
(\mathrm{mm})\end{array}$ \\
\hline \multirow{4}{*}{ Humid } & Ankang & 32.7 & 109 & 895 & 1.56 & 11.6 & 316.0 \\
\hline & Hanzhong & 33.1 & 107.1 & 895 & 1.56 & 10.3 & 352.5 \\
\hline & Fopimh & 33.6 & 108 & 1840 & 1.75 & 8.8 & 310.2 \\
\hline & Shangluo & 33.9 & 110 & 1100 & 1.31 & 8.9 & 273.8 \\
\hline \multirow{4}{*}{$\begin{array}{l}\text { Semi- } \\
\text { humid }\end{array}$} & Wugong & 34.3 & 108.2 & 426 & 1.14 & 8.7 & 228.1 \\
\hline & Fengxiang & 34.5 & 107.4 & 690 & 1.23 & 8.0 & 184.9 \\
\hline & Tongchuan & 35.1 & 109.1 & 1040 & 1.36 & 6.3 & 206.7 \\
\hline & Yanan & 36.6 & 109.5 & 1146 & 0.92 & 5.5 & 152.0 \\
\hline \multirow{4}{*}{ Semi-arid } & Wuqi & 36.9 & 108.2 & 1060 & 0.87 & 3.2 & 150.8 \\
\hline & Suide & 37.5 & 110.2 & 1052 & 0.48 & 4.6 & 121.8 \\
\hline & Dingbian & 37.6 & 107.6 & 1500 & 0.54 & 3.9 & 95.7 \\
\hline & Yulin & 38.3 & 109.8 & 1400 & 0.84 & 2.9 & 102.9 \\
\hline
\end{tabular}


Table 2 Calibration results of the treatment with sufficient irrigation and fertilization from 2014-2015

\begin{tabular}{|c|c|c|c|c|c|c|c|c|c|c|c|c|c|c|}
\hline \multicolumn{3}{|c|}{ Anthesis (DAS) } & \multicolumn{3}{|c|}{ Maturity (DAS) } & \multicolumn{3}{|c|}{ Yield $\left(\mathrm{kg} \mathrm{hm}^{-2}\right)$} & \multicolumn{3}{|c|}{ GNC $\left(\mathrm{kg} \mathrm{N} \mathrm{hm}^{-2}\right)$} & \multicolumn{3}{|c|}{$\mathrm{ET}(\mathrm{mm})$} \\
\hline sim. & obs. & $d(\%)$ & sim. & obs. & $d(\%)$ & sim. & obs. & $d(\%)$ & sim. & obs. & $d(\%)$ & sim. & obs. & $d(\%)$ \\
\hline 199 & 199 & 0 & 233 & 233 & 0 & 8025 & 8287 & -3.16 & 165 & 169 & -5.22 & 458 & 469 & -2.34 \\
\hline
\end{tabular}

Note: Sim., simulated values; Obs., observed values; d, percent deviation values; DAS, days after sowing; GNC, grain nitrogen concentration; ET, evapotranspiration. 
Table 3 Number and $\mathbf{r}^{2}$ of calibration periods and validation periods for temperature, precipitation and radiation between predictand variables and predictor variables

\begin{tabular}{|c|c|c|c|c|c|}
\hline \multirow{2}{*}{$\begin{array}{l}\text { Predictand } \\
\text { variables }\end{array}$} & \multirow{2}{*}{ Predictor variables (NCEP Reanalysis) } & \multicolumn{2}{|c|}{ Calibration periods } & \multicolumn{2}{|c|}{ Validation periods } \\
\hline & & Number & $\mathrm{r}^{2}$ & Number & $\mathrm{r}^{2}$ \\
\hline Tmax & $\begin{array}{l}\text { Mean sea level pressure, Specific humidity at } 850 \mathrm{hPa} \text {, } \\
\text { Wind strength at } 850 \mathrm{hPa} \text {, Southerly wind at } 850 \mathrm{hPa} \text {, } \\
\text { the surface Zonal velocity component, } 850 \mathrm{hPa} \text { height } \\
\text { Zonal velocity component }\end{array}$ & 10957 & $0.8718 * * *$ & 5479 & $0.8088 * * *$ \\
\hline Tmin & $\begin{array}{l}\text { Mean sea level pressure, the surface Zonal velocity } \\
\text { component, } 500 \mathrm{hPa} \text { height Geostrophic air flow } \\
\text { velocity, } 500 \mathrm{hPa} \text { geopotential height, } 850 \mathrm{hPa} \text { height } \\
\text { Zonal velocity component, Near surface specific } \\
\text { humidity }\end{array}$ & 10957 & $0.9429 * * *$ & 5479 & $0.9301 * * *$ \\
\hline Precipitation & $\begin{array}{l}\text { The surface Meridional velocity component, } 500 \mathrm{hPa} \\
\text { height Meridional velocity component, Specific } \\
\text { humidity at } 500 \mathrm{hPa} \text { height, Near surface specific } \\
\text { humidity }\end{array}$ & 360 & $0.6373 * * *$ & 180 & $0.5465 * * *$ \\
\hline Radiation & $\begin{array}{l}\text { Mean sea level pressure, } 500 \mathrm{hPa} \text { height Meridional } \\
\text { velocity component, } 500 \mathrm{hPa} \text { geopotential height, } 500 \\
\mathrm{hPa} \text { height Wind direction, } 850 \mathrm{hPa} \text { geopotential } \\
\text { height, Mean temperature at } 2 \mathrm{~m}\end{array}$ & 360 & $0.8857 * * *$ & 180 & $0.9018 * * *$ \\
\hline
\end{tabular}

Note: $* * *$ significant at $\mathrm{P}<0.001$. 